\title{
Effect of Cooking Time on the Physical, Chemical and Thermal Properties of Acha Seeds
}

\author{
Akeem O. Raji ${ }^{a^{*}}$, Hajarat O. Nassam ${ }^{a}$, Tawakalitu E. Aruna ${ }^{a}$, Monsurat O. \\ RAJi ${ }^{b}$, AND MAIMUNA SANI ${ }^{\mathrm{a}}$ \\ ${ }^{\text {a }}$ Department of Food Agric and Biological Engineering, College of Engineering and Technology, Kwara State \\ University, Malete, Ilorin, Nigeria \\ b DDepartment of Food Technology, University of Ibadan, Oyo State, Nigeria \\ ${ }^{*}$ Corresponding author \\ akeem.raji@kwasu.edu.ng
}

Received: 31 October 2017; Published online: 18 October 2017

\begin{abstract}
Acha is a less utilized cereal grain in Africa. Scaling up of the processing technology of acha seeds is desirable if accurate information on effect of processing on its properties is available. This study investigated the effect of cooking duration on the chemical and physical properties of acha seeds. Cooking times $\left(2.5,5,7.5\right.$ and 10 minutes) at $100^{\circ} \mathrm{C}$ were used. The volume, length, breadth, thickness, porosity, density, sphericity, aspect ratio, specific heat capacity, thermal conductivity, thermal diffusivity, moisture, protein, fat, ash, crude fibre and carbohydrate were determined using standard methods. Data were analysed using ANOVA at $\mathrm{p}=0.05$. The results obtained revealed that varietal difference had a significant effect on volume, length, breadth, thickness, true density, bulk density, porosity, sphericity and aspect ratio. The moisture content, ash, protein, crude fibre, fat, carbohydrate, specific heat capacity, thermal conductivity and thermal diffusivity varied from $8.80-56.17 \%, 0.32-1.87 \%, 1.92$ $11.50 \%, 0.29-1.58 \%, 0.32-2.81 \%, 40.94-76.26 \%, 1.66-2.97 \mathrm{kJkg}^{-1} \mathrm{~K}^{-1}, 0.26-0.43 \mathrm{Wm}^{-1} \mathrm{~K}^{-1}$ and $0.85 \times 10^{-7}-1.17 \times 10^{-7} \mathrm{~ms}^{-2}$ respectively, as significantly influenced by cooking time. Cooking for 7.5 minutes was appropriate using the moisture uptakes and thermal properties as criteria.
\end{abstract}

Keywords: Acha seeds; Cooking duration; Physical properties; Proximate composition; Thermal properties

\section{Introduction}

Acha (Digistiria exilis staph and Digistiria iburua kippis) is one of lesser known cereals found in Africa and it is sometimes referred to as Hungry Rice (NAS, 1996). It has important potential not only as a survival food, but also as a complement for standard diets (NAS, 1996). Acha is easily digested, and it is traditionally recommended for children, old people that cannot digest other cereals, sick people, diabetic patients and patients with stomach diseases (Cruz, 2004). The diets from acha have relatively low free sugar and low glycemic content, which makes it adequate as a suggested diet for diabetic patients (Obizoba \& Anyika, 1994). Acha has high water absorption capacity that gives it ability to be utilized in baked foods. Its amino acid profile was compared to that of whole-egg protein, and showed that acha was rich in essential amino acids except for the low score of $46 \%$ in lysine. It also contains pentosans (Lasekan, 1994) which gives it the ability to form a gel in the presence of oxidizing agents at room temperature. The high levels of sulphur containing and hydrophobic amino acids in acha grains make it a use- 
ful crop for bakery products (Obizoba \& Anyika, 1994).

Engineering properties of crops are essential parameters in utilisation, development of processing methods and design of processing equipment (Akinoso \& Raji, 2011). Such properties include rheological, thermal, optical, electrical, physical and mechanical properties. Some published works on engineering properties of agricultural products are on dika nut (Ogunsina \& Koya, 2008), soybean (Kibar \& Ozturk, 2008), wheat straw (Tavakoli, Mohtasebi, \& Jafari, 2009), maize grain (Chemperek \& Rydzak, 2006), faba bean (Altuntas \& Yildiz, 2007) and pea seed (Andrejko, Rydzak, Slaska-Grzywna, Gozdziewska, \& Kobus, 2008). Researchers have clearly shown that engineering properties of biomaterial significantly depend on primary processing conditions. Therefore, improvement of the processing technology of acha seeds requires accurate information on the chemical, thermo-physical and mechanical properties of the grain, as affected by primary processing. Studies on cooking time reduction, without compromising food value, will provide information that can be used to reduce energy demand and encourage interest in its consumption, thereby increasing its utilization. The aim of this research work was to determine effect of cooking duration on some engineering properties and proximate composition of cooked acha seeds.

\section{Materials and Methods}

\subsection{Samples Preparation}

The two varieties of acha seeds used for this study were purchased from Sokoto State, Nigeria. Cooking durations were $2.5,5,7$ and 10 minutes, at atmospheric pressure $(760 \mathrm{~mm} \mathrm{Hg}$ $\approx 1$ bar $)$ and boiling temperature $\left(100^{\circ} \mathrm{C}\right)$. The acha seeds were cooked in distilled water using a $3 \mathrm{~mm}$ thick stainless steel container placed on a kerosene stove. At attainment of the desired heating duration, the container was removed and the water was drained off after which the acha seeds were cooled to ambient temperature $\left(29^{\circ} \mathrm{C}\right)$ in desiccators containing silica gel as a desiccant.

\subsection{Physical Properties}

A preliminary investigation was carried out in order to establish some physical properties of the two varieties of acha seeds that are common in Nigeria. Physical properties such as size (length, breadth, thickness), mass, shape and porosity of the samples, were determined directly using standard methods (Akinoso \& Raji, 2011). The true density was determined by weighing $30 \mathrm{~g}$ of each sample into $100 \mathrm{~cm}^{3}$ graduated cylinders and the volume of the tiny seeds was recorded and expressed as $\mathrm{kg} / \mathrm{m}^{3}$, while the tapped density was determined by weighing $30 \mathrm{~g}$ of each sample into $100 \mathrm{~cm}^{3}$ graduated cylinders which were then tapped ten times against the palm. The volume of the tiny seeds after tapping was recorded and expressed as $\mathrm{kg} / \mathrm{m}^{3}$ (Akinoso \& Raji, 2011).

$$
\begin{gathered}
\text { True Density, } \rho_{t}=\frac{\text { Mass }}{\text { Volume }} \\
\text { Bulk Density, } \rho_{b}=\frac{\text { Mass }}{\text { Volume }(\text { tapped })} \\
\varepsilon=\frac{\rho_{t}-\rho_{b}}{\rho_{t}} \times 100
\end{gathered}
$$

where $\varepsilon=$ Porosity, $\rho_{b}=$ Bulk density, $\mathrm{kg} / \mathrm{m}^{3}$ and $\rho_{t}=$ True density, $\mathrm{kg} / \mathrm{m}^{3}$.

The length, breadth and thickness of the seeds were determined using a micrometer with 0.01mm accuracy (Cappera precision, China). A digital weighing balance (Scout ${ }^{\mathrm{TM}}$ Pro OHaus model SPU 401) of accuracy $\pm 0.001 \mathrm{~g}$ was used for mass measurement. The sphericity and aspect ratio were determined according to Mohsenin (1986), using Equations 4 and 5, respectively.

$$
\begin{aligned}
S I & =(\alpha \beta \delta)^{\frac{1}{3}} \\
R a & =\frac{\beta}{\alpha} \times 100
\end{aligned}
$$

where SI is sphericity (\%), Ra is aspect ratio (\%), and $\alpha, \beta$ and $\delta$ are length, breadth and thickness in $\mathrm{mm}$ respectively. 


\subsection{Chemical Analyses}

The proximate compositions (moisture, protein, ash, fat, crude fibre and carbohydrate) of the acha samples were evaluated using the standard AOAC procedure (AOAC, 2005).

\subsection{Determination of Thermal Properties}

The specific heat capacity, thermal conductivity and thermal diffusivity of the acha samples were determined as a function of their proximate compositions by applying additivity principles.

\section{Specific Heat Capacity $\left(\mathbf{C}_{p}\right)$ and Thermal Conductivity (K)}

The above parameters were determined based on weight fraction of water, fat, ash, protein and carbohydrate component of food using the equations stated below (Choi \& Okos, 1986).

$$
\begin{array}{r}
C_{p}=1.424 X_{c}+1.549 X_{p}+1.675 X_{f}+\ldots \\
\ldots+0.837 X_{a}+4.187 X_{w} \\
k=0.58 X_{w}+0.155 X_{p}+0.25 X_{c}+\ldots \\
\ldots+0.16 X_{f}+0.135 X_{a}
\end{array}
$$

\section{Thermal Diffusivity}

Thermal diffusivity of each sample was determined based on weight fraction of water, fat, protein and carbohydrate components of the food, using the equation stated below (Choi \& Okos, 1986).

$$
\begin{aligned}
D= & 0.146 * 10^{-6} X_{w}+0.10 * 10^{-6} X_{f}+\ldots \\
& \ldots+0.075 * 10^{-6} X_{p}+0.082 * 10^{-6} X_{c}
\end{aligned}
$$

where $\mathrm{X}$ is the fraction of food component, and the subscripts w, f, p, c and a represent water, fat, protein, carbohydrate and ash respectively.

\subsection{Statistical Analysis:}

Data obtained were analyzed using SPSS version 14.0, Chicago.

\section{Results and Discussion}

\subsection{Size Characteristics}

Length, breadth and thickness of the acha varieties were $0.57 \pm 0.03 \mathrm{~mm}, 0.53 \pm 0.06 \mathrm{~mm}$ and $0.53 \pm 0.06 \mathrm{~mm}$ for the white variety and $0.53 \pm 0.03 \mathrm{~mm}, 0.47 \pm 0.03 \mathrm{~mm}$ and $0.42 \pm 0.03$ $\mathrm{mm}$ for the brown variety, respectively (Table 1). Seed size is important in the design and selection of equipment for primary processing of separation (Akinoso \& Raji, 2011). All the above physical properties measured showed some deviations from the average values which is typical of agricultural biomaterials.

\subsection{Density and Porosity}

The results of the true density and bulk density of the two varieties of acha seeds are shown in Table 1 , with the white variety having the highest values $\left(867.28 \pm 17.17 \mathrm{kgm}^{-3}\right.$ and $877.37 \pm 15.40$ $\mathrm{kgm}^{-3}$ respectively) and the brown variety having the lowest values $\left(810.86 \pm 7.63 \mathrm{kgm}^{-3}\right.$ and $\left.838.04 \pm 8.16 \mathrm{kgm}^{-3}\right)$. Bulk density has practical application in determining separation of product from undesirable materials (Fellows, 2000). Cleaning is an important unit operation in food processing (Fellows, 2000). It was observed that brown acha, with smallest dimensions, had the lowest bulk density. This could be attributed to the fact that white acha seeds are likely to be better compacted than the brown acha seeds. This is in agreement with findings of Tunde-Akintunde and Akintunde (2007) who reported that smaller seeds had smaller bulk density than the bigger seeds. The porosity of the white acha seeds was $0.01 \pm 0.01$, and that of the brown acha seeds was $0.03 \pm 0.02$ (Table 1). It was observed that white acha seed with the highest bulk density and moisture content had the lowest porosity. This indicates that there is an inverse relationship between the bulk density and porosity. Porosity is an essential characteristic used in the calcu- 
Effect of Cooking Time on Properties of Acha Seeds |181

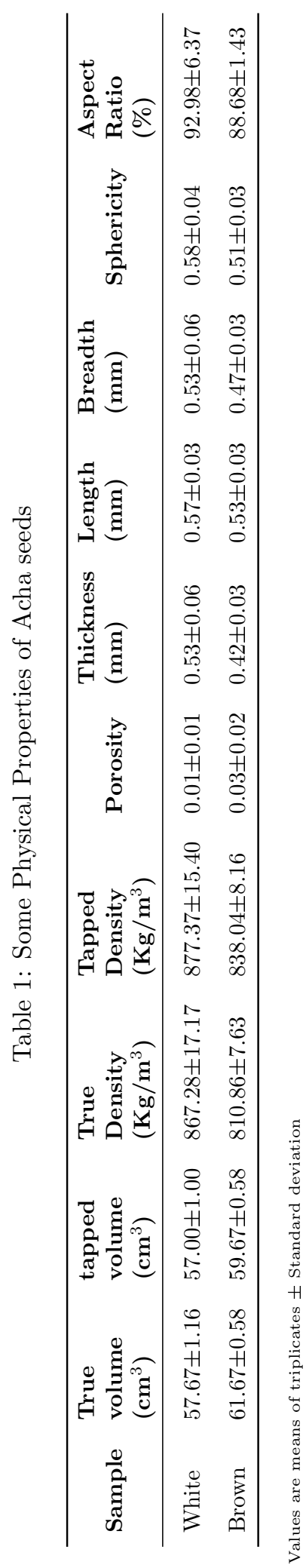

IJFS | October 2017 | Volume 6 | pages 178-191 
Table 2: Effect of Cooking Time on the Proximate Composition of White Acha Seeds

\begin{tabular}{lllllll}
\hline $\begin{array}{l}\text { Cooking } \\
\text { Time }(\mathbf{m i n})\end{array}$ & $\begin{array}{l}\text { Protein } \\
\mathbf{( \% )}\end{array}$ & $\begin{array}{l}\text { Crude Fibre } \\
\mathbf{( \% )}\end{array}$ & $\begin{array}{l}\text { Fat } \\
(\mathbf{\%})\end{array}$ & $\begin{array}{l}\text { Ash } \\
(\mathbf{\%})\end{array}$ & $\begin{array}{l}\text { Moisture } \\
(\mathbf{\%})\end{array}$ & $\begin{array}{l}\text { Carbohydrate } \\
\mathbf{( \% )}\end{array}$ \\
\hline 0.00 & $9.40 \pm 0.10^{a}$ & $1.58 \pm 0.02^{a}$ & $1.44 \pm 0.01^{a}$ & $1.45 \pm 0.05^{a}$ & $9.87 \pm 0.23^{d}$ & $76.26 \pm 0.18^{a}$ \\
2.50 & $2.48 \pm 0.03^{b}$ & $0.44 \pm 0.02^{b}$ & $0.40 \pm 0.01^{b}$ & $0.41 \pm 0.01^{b}$ & $37.91 \pm 0.09^{c}$ & $58.36 \pm 0.08^{b}$ \\
5.00 & $2.08 \pm 0.07^{c}$ & $0.36 \pm 0.01^{c}$ & $0.35 \pm 0.02^{c}$ & $0.38 \pm 0.01^{b c}$ & $50.83 \pm 0.76^{b}$ & $46.00 \pm 0.85^{c}$ \\
7.50 & $2.00 \pm 0.00^{c d}$ & $0.36 \pm 0.01^{c}$ & $0.32 \pm 0.02^{d}$ & $0.34 \pm 0.01^{c d}$ & $55.67 \pm 0.58^{a}$ & $41.31 \pm 0.59^{d}$ \\
10.00 & $1.92 \pm 0.08^{d}$ & $0.34 \pm 0.01^{c}$ & $0.32 \pm 0.01^{d}$ & $0.32 \pm 0.01^{d}$ & $56.17 \pm 0.76^{a}$ & $40.94 \pm 0.84^{d}$ \\
\hline
\end{tabular}

Values are means of three replicates. Mean values having different superscripts within a column are significantly different $(\mathrm{p}<0.05)$

lation of rate of aeration, cooling, drying and heating. It is also used in the design of heat exchangers and packaging equipment (Davies \& Zibokere, 2011).

\subsection{Shape}

The mean sphericity and aspect ratio of the samples varied from $0.51 \pm 0.03$ to $0.58 \pm 0.04 \%$, and $88.68 \pm 1.48$ to $92.98 \pm 6.37 \%$, respectively (Table $1)$. The range of sphericity and aspect ratio observed in this study were low, when compared with the values reported by Mohsenin (1986) for plant seeds. High sphericity and aspect ratio are indications of seeds that tend to a spherical shape. These properties are useful in the design of dehulling equipment Mohsenin (1986).

\subsection{Effects of Cooking on the Proximate Composition Acha Seeds}

Proximate compositions of the acha seeds are presented in Table 2-3. The cooking durations had significant influence on all the determined chemical properties at the $95 \%$ confidence level. A similar observation on wheat cooked at temperatures of $80^{\circ} \mathrm{C}, 100^{\circ} \mathrm{C}$ and $120^{\circ} \mathrm{C}$ was reported by Chukwu, Sunmonu, and Ismaila (2011).

\section{Protein}

The protein content of the white acha samples varied from $1.92 \pm 0.08$ to $9.40 \pm 0.10 \%$, and that of the brown samples varied from $2.03 \pm$ 0.06 to $11.50 \pm 0.50 \%$. It was observed that as the cooking duration increased the protein content was reduced. This is similar to previous work reported on the decrease in protein content of Canavalia cathartica from 32.1 to $28.1 \%$ after cooking (Seena, Sridhar, Arun, \& Young, 2006). In addition, Baiyeri, Aba, Otitoju, and Mbah (2011) reported a reduction in protein content of cooked banana from 3.21 to $2.48 \%$. Protein quality is a measure of the usefulness of a food protein for the purpose of growth and maintenance of tissue. Reduction in crude protein content was due to thermal denaturation that resulted in coagulation and decreased solubility of protein (Akinoso \& El-alawa, 2013).

\section{Fat}

The fat content of the white acha samples varied from $0.32 \pm 0.01$ to $1.44 \pm 0.01 \%$, and that of the brown samples varied from $0.64 \pm 0.01$ to 2.81 $\pm 0.02 \%$. It was noticed that cooking reduced the fat content of acha seeds significantly at the 95\% confidence level. Heating fractionated the intact oil bodies and ruptured cellular structure (Akinoso \& El-alawa, 2013).

\section{Carbohydrate}

The carbohydrate content of the white acha samples varied from $40.94 \pm 0.84$ to $76.26 \pm 0.18 \%$, and that of the brown samples varied from 42.60 \pm 0.34 to73.58 $\pm 0.45 \%$. The remarkable reduction in the carbohydrate content was due to hydrolysis of starch to simple sugars during the cooking period. Hydrophilic groups in carbohydrate molecules caused it to take up moisture in proportion to the relative humidity of the environment (Akinoso \& El-alawa, 2013). This char- 
Effect of Cooking Time on Properties of Acha Seeds | 183

Table 3: Effect of Cooking Time on the Proximate Composition of Brown Acha Seeds

\begin{tabular}{lllllll}
\hline $\begin{array}{l}\text { Cooking } \\
\text { Time }(\mathbf{m i n})\end{array}$ & $\begin{array}{l}\text { Protein } \\
\mathbf{( \% )}\end{array}$ & $\begin{array}{l}\text { Crude Fibre } \\
\mathbf{( \% )}\end{array}$ & $\begin{array}{l}\text { Fat } \\
\mathbf{( \% )}\end{array}$ & $\begin{array}{l}\text { Ash } \\
\mathbf{( \% )}\end{array}$ & $\begin{array}{l}\text { Moisture } \\
\mathbf{( \% )}\end{array}$ & $\begin{array}{l}\text { Carbohydrate } \\
\mathbf{( \% )}\end{array}$ \\
\hline 0.00 & $11.50 \pm 0.50^{a}$ & $1.45 \pm 0.05^{a}$ & $2.81 \pm 0.02^{a}$ & $1.87 \pm 0.15^{a}$ & $8.80 \pm 0.20^{d}$ & $73.58 \pm 0.45^{a}$ \\
2.50 & $2.74 \pm 0.01^{b}$ & $0.36 \pm 0.01^{b}$ & $0.73 \pm 0.03^{b}$ & $0.48 \pm 0.01^{b}$ & $37.89 \pm 0.11^{c}$ & $57.80 \pm 0.16^{b}$ \\
5.00 & $2.28 \pm 0.03^{c}$ & $0.32 \pm 0.02^{b c}$ & $0.68 \pm 0.04^{b c}$ & $0.40 \pm 0.02^{b c}$ & $48.50 \pm 0.50^{b}$ & $47.83 \pm 0.54^{c}$ \\
7.50 & $2.14 \pm 0.04^{c}$ & $0.29 \pm 0.01^{c}$ & $0.68 \pm 0.04^{b c}$ & $0.35 \pm 0.01^{b c}$ & $53.67 \pm 0.58^{a}$ & $42.86 \pm 0.65^{d}$ \\
10.00 & $2.03 \pm 0.06^{c}$ & $0.29 \pm 0.01^{c}$ & $0.64 \pm 0.01^{c}$ & $0.34 \pm 0.01^{c}$ & $54.10 \pm 0.36^{a}$ & $42.60 \pm 0.34^{d}$ \\
\hline
\end{tabular}

Values are means of three replicates. Mean values having different superscripts within a column are significantly different $(\mathrm{p}<0.05)$

acteristic increase in moisture uptake might result in the apparent reduction in percentage of carbohydrate.

\section{Crude Fibre}

The crude fibre content of the white acha samples varied from $0.34 \pm 0.01$ to $1.58 \pm 0.02 \%$, and that of the brown samples varied from 0.29 \pm 0.01 to $1.45 \pm 0.05 \%$. It was observed that as the cooking duration increased the crude fibre content reduced. Losses in crude fibre might be due to thermal-induced degradation. Adequate intake of dietary fiber can lower the level of serum cholesterol and reduce the risk of developing hypertension, constipation, diabetes, colon, cancer and coronary heart disease (Ishida et al., 2000). The lowest value $(0.41 \%)$ of crude fiber content for the uncooked acha seeds was reported by Jideani and Akingbala (1993) while the highest value $(11.3 \%)$ was reported by Serna (2003). The high variation in the crude fiber contents of fonio grains could also be attributed to environmental influences, geographical location, agronomic factors, genetic factors and different analytical methods.

\section{Ash}

The ash content of the white acha samples varied from $0.32 \pm 0.01$ to $1.45 \pm 0.05 \%$, and that of the brown samples varied from $0.34 \pm 0.01$ to $1.87 \pm 0.15 \%$. It was observed that as the cooking duration increased the ash content reduced. The ash contents $(1.45 \pm 0.05 \%$ (white) and 1.87 $\pm 0.15 \%$ (brown)) obtained for uncooked acha seeds in this study were slightly higher than the $1.0 \%$ found by Jideani and Akingbala (1993) and Fliedel, Ouattara, Grabulos, Drame, and Cruz (2004), but lower than the $6.0 \%$ value reported by Serna (2003). Ash content is an index of mineral content in biota (Akubugwo, Obasi, Chinyere, \& Ugbogu, 2007). The observed high ash content in the uncooked brown acha seeds indicates higher amounts of minerals in brown acha seeds compared to the white varieties.

\section{Moisture Content}

The moisture content of the white acha samples varied from $9.87 \pm 0.23$ to $56.17 \pm 0.76 \%$, and that of the brown samples varied from $8.80 \pm$ 0.20 to $54.10 \pm 0.36 \%$. Cooking of acha seeds for 10 minutes significantly increased moisture levels of the seeds. Moisture uptake of $46.14 \%$ was recorded. Significant changes in chemical composition of the seeds during cooking might be attributed to water absorption capacity of the biomaterials which causes re-distribution of chemicals within the seeds (Akinoso \& El-alawa, 2013). The moisture content of seeds determines their susceptibility to microbial attack and hence spoilage (Olusanya, 2008). The observed low moisture content in the uncooked brown acha seeds could mean that the brown acha seeds might have storage advantage over that of white. 


\subsection{Relationship between the Moisture Content and Thermal Properties of Uncooked and Cooked Acha Seeds}

Thermal properties express the reaction of a substance when a change in temperature occurs. The relationships between the moisture uptake of acha seeds during cooking and the thermal properties of acha seeds are shown in Figures 1 and 2 . The moisture content of the white acha samples varied from $9.87 \pm 0.23$ to $56.17 \pm 0.76 \%$, and that of the brown samples varied from $8.80 \pm$ 0.20 to $54.10 \pm 0.36 \%$. The specific heat capacity of the white acha samples varied from 1.68 to 2.97 $\mathrm{kJkg}^{-1} \mathrm{~K}^{-1}$ and that of the brown samples varied from 1.66 to $2.92 \mathrm{kJkg}^{-1} \mathrm{~K}^{-1}$. The thermal conductivity of the white acha samples and brown samples varied from 0.27 to $0.43 \mathrm{Wm}^{-1} \mathrm{~K}^{-1} 1$ and 0.26 to $0.43 \mathrm{Wm}^{-1} \mathrm{~K}^{-1}$ respectively. The thermal diffusivity of the white acha samples varied from $0.86 \times 10^{-7}$ to $1.17 \times 10^{-7} \mathrm{~ms}^{-2}$ and that of the brown samples varied from $0.85 \mathrm{x}$ $10^{-7}$ to $1.16 \times 10^{-7} \mathrm{~ms}^{-2}$. It was observed that there were linear relationships between the moisture uptakes of the two varieties of acha seeds during cooking and the thermal properties (the specific heat capacity, the thermal conductivity and thermal diffusivity). The high coefficients of determination $\mathrm{R}^{2}$ indicate that the linear model equations established in Figures 1 and 2 had good fits.

However, the effect of variation in composition of a food on thermal properties had been previously reported (Choi \& Okos, 1986). Design of an efficient boiler is a function of thermal properties (Barbosa-Canovas, Juliano, \& Peleg, 2006). Specific heat capacity determines the amount of heat a substance can absorb (Singh \& Heldman, 2001). The values obtained in this study are below the specific heat capacity of water. Lewicki (2004) proved that there was a direct correlation between the specific heat capacity and moisture content of a food product. This implied that as the moisture content increased, the specific heat capacity increased. This was observed in the cooked acha samples, with the white acha samples having the highest moisture content and specific heat capacity. The thermal conductivity of a material is a measure of its ability to transmit heat (Singh \& Heldman, 2001). High values were reported for acha seeds cooked for 10 minutes, with the white variety having the highest values. This connotes that white acha seeds will have greater advantage for absorption and dissipation of heat during processing and storage than brown acha seeds. Thermal conductivity of food depends on the structure and chemical composition of the sample and it increases with increasing water content for all food products at temperature above freezing (Ishida et al., 2000). Bamgboye and Adejumo (2010) reported a rise in thermal conductivity of Roselle seed from 1.56 to $1.22 \mathrm{Wm}^{-1} \mathrm{~K}^{-1}$ with increased moisture content of 8.8 to $19.0 \%$, respectively. Therefore, an increase in temperature might have also influenced their results. Similar results were obtained in this study for the thermal conductivity of cooked and uncooked acha seeds. The thermal diffusivity quantifies a material's ability to conduct heat relative to its ability to store heat (Stroshine \& Hamann, 1994). The results in this study indicated that thermal diffusivity increased with increase in moisture content, as was observed for thermal conductivity and specific heat capacity of the acha samples.

\subsection{Relationship between the Cooking Duration and Thermal Properties of Acha Seeds}

The effect of cooking time on the thermal properties of acha seeds are shown in Figures 3 and 4. The cooking duration had significant influence on all the determined thermal properties. It was observed that as the cooking duration increased, the thermal properties increased. Predictive model equations were developed for the relationships between the cooking time and the thermal properties (specific heat capacity, thermal conductivity and thermal diffusivity). High coefficients of determination $\mathrm{R}^{2}$ suggested that all the models had good fits (Figures 3 and 4). The values for the specific heat capacity of the acha samples were lower than specific heat capacity of $1.39 \mathrm{kJkg}^{-1} \mathrm{~K}^{-1}$ for guna seed (Aviara, 
Effect of Cooking Time on Properties of Acha Seeds | 185

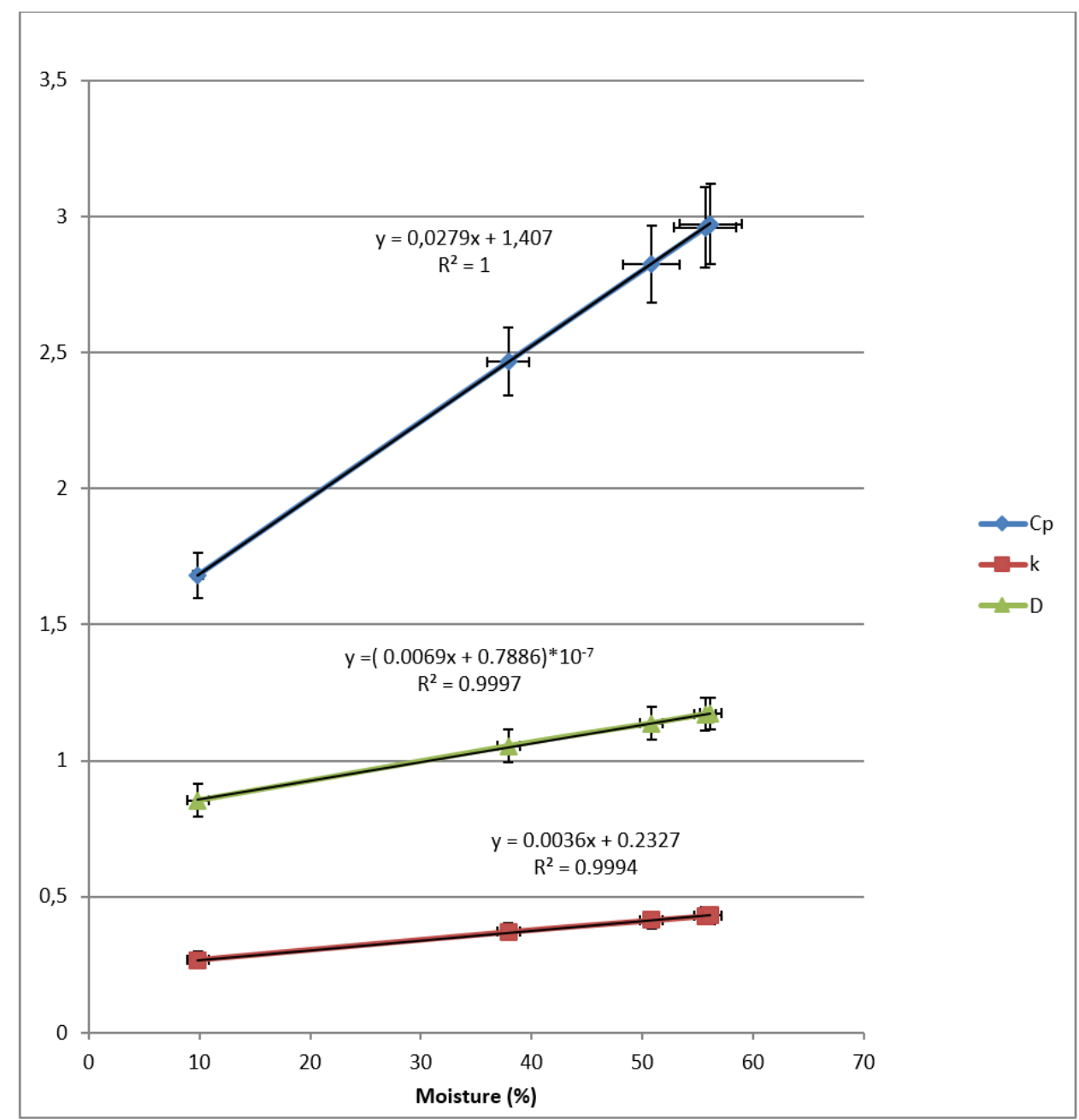

Figure 1: Influence of Moisture Content on the Thermal Properties of Cooked and Uncooked White Acha Seeds. $\mathrm{Cp}=$ Specific Heat Capacity, $\mathrm{kJkg}^{-1} \mathrm{~K}^{-1}, \mathrm{~K}=$ Thermal Conductivity, $\mathrm{Wm}^{-1} \mathrm{~K}^{-1}$, $\mathrm{D}=$ Thermal Diffusivity, $\mathrm{ms}^{-2} \cdot 10^{-7}$ 
$186 \mid$ Raji et al.

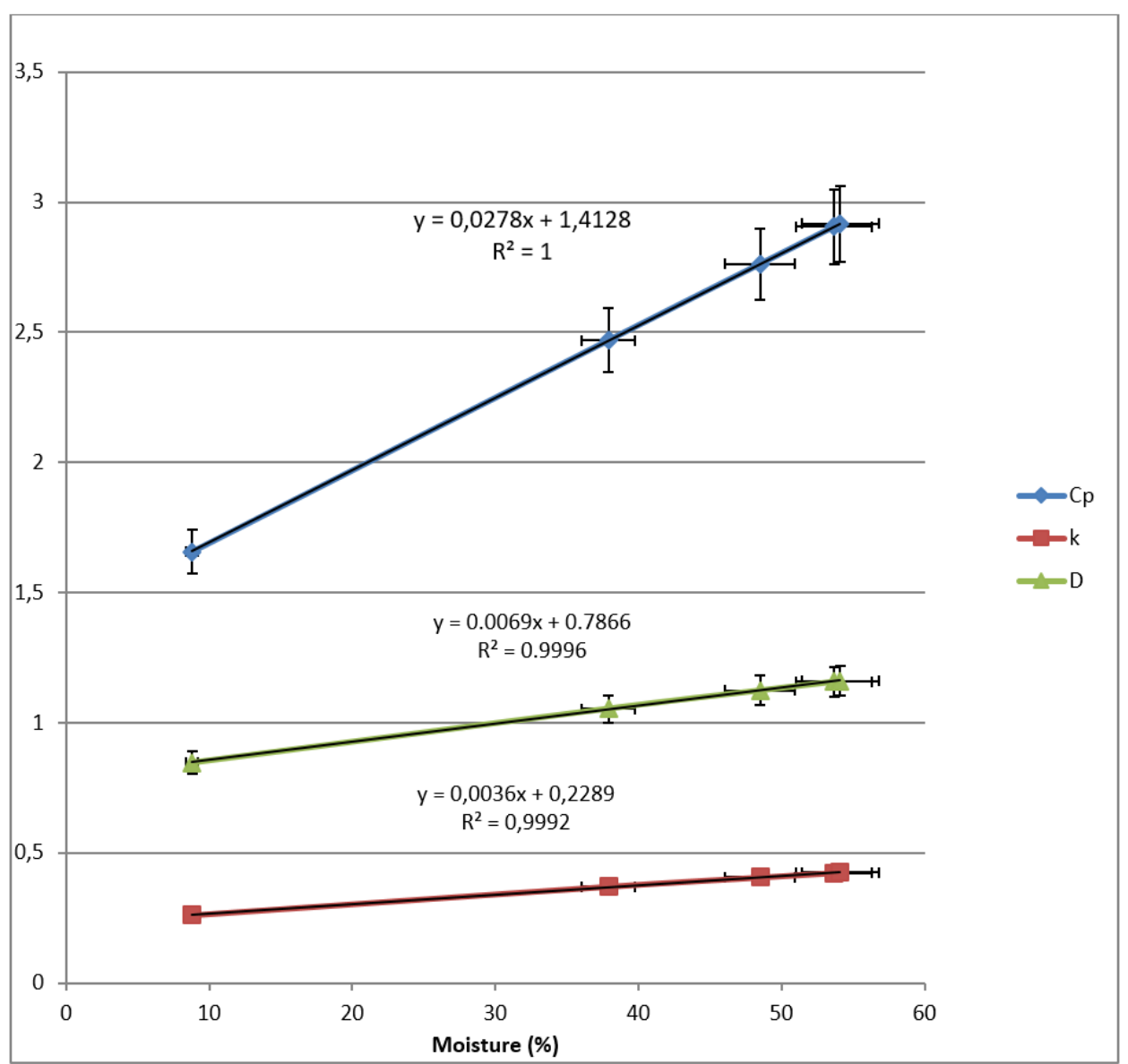

Figure 2: Influence of Moisture Content on the Thermal Properties of Cooked and Uncooked Brown Acha Seeds. $\mathrm{Cp}=$ Specific Heat Capacity, $\mathrm{kJkg}^{-1} \mathrm{~K}^{-1}, \mathrm{~K}=$ Thermal Conductivity, $\mathrm{Wm}^{-1} \mathrm{~K}^{-1}, \mathrm{D}=$ Thermal Diffusivity, $\mathrm{ms}^{-2} \cdot 10^{-7}$

Haque, \& Ogunjimi, 2008) and $5.63 \mathrm{kJkg}^{-1} \mathrm{~K}^{-1}$ for roselle seed (Bamgboye \& Adejumo, 2010). Specific heat is an essential parameter in design of heat exchangers. The information will be useful for selection of heat transfer medium and processing conditions (Akinoso \& El-alawa, 2013). Thermo-physical properties are significantly dependent on changes in moisture content and temperature (Barbosa-Canovas et al., 2006). Thermal conductivity is important to predict or control heat flux and processing time. This ensures the efficiency of equipment, improves economics of the process, and enhances quality of the product (Akinoso \& El-alawa, 2013). Thermal diffu- sivity relates to the ability of the material to conduct heat compared to its ability to store heat. Thermal diffusivity is the ratio of thermal conductivity to density and specific heat. Therefore, speed of heat diffusion through a material is also relevant information in processing time prediction models (Akinoso \& El-alawa, 2013). 
Effect of Cooking Time on Properties of Acha Seeds |187

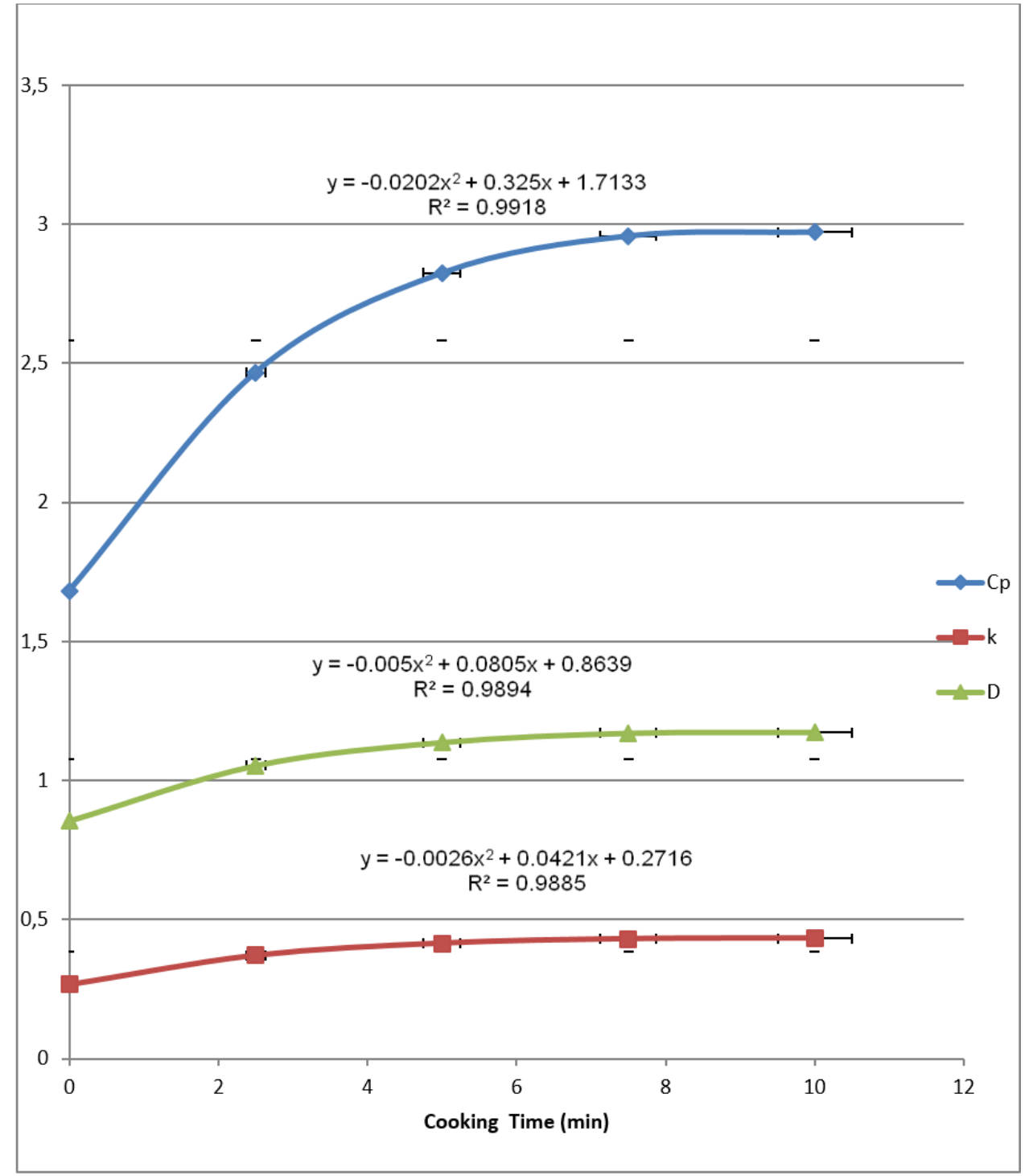

Figure 3: Effect of Cooking Time on the Thermal Properties of White Acha Seeds 
188 | Raji et al.

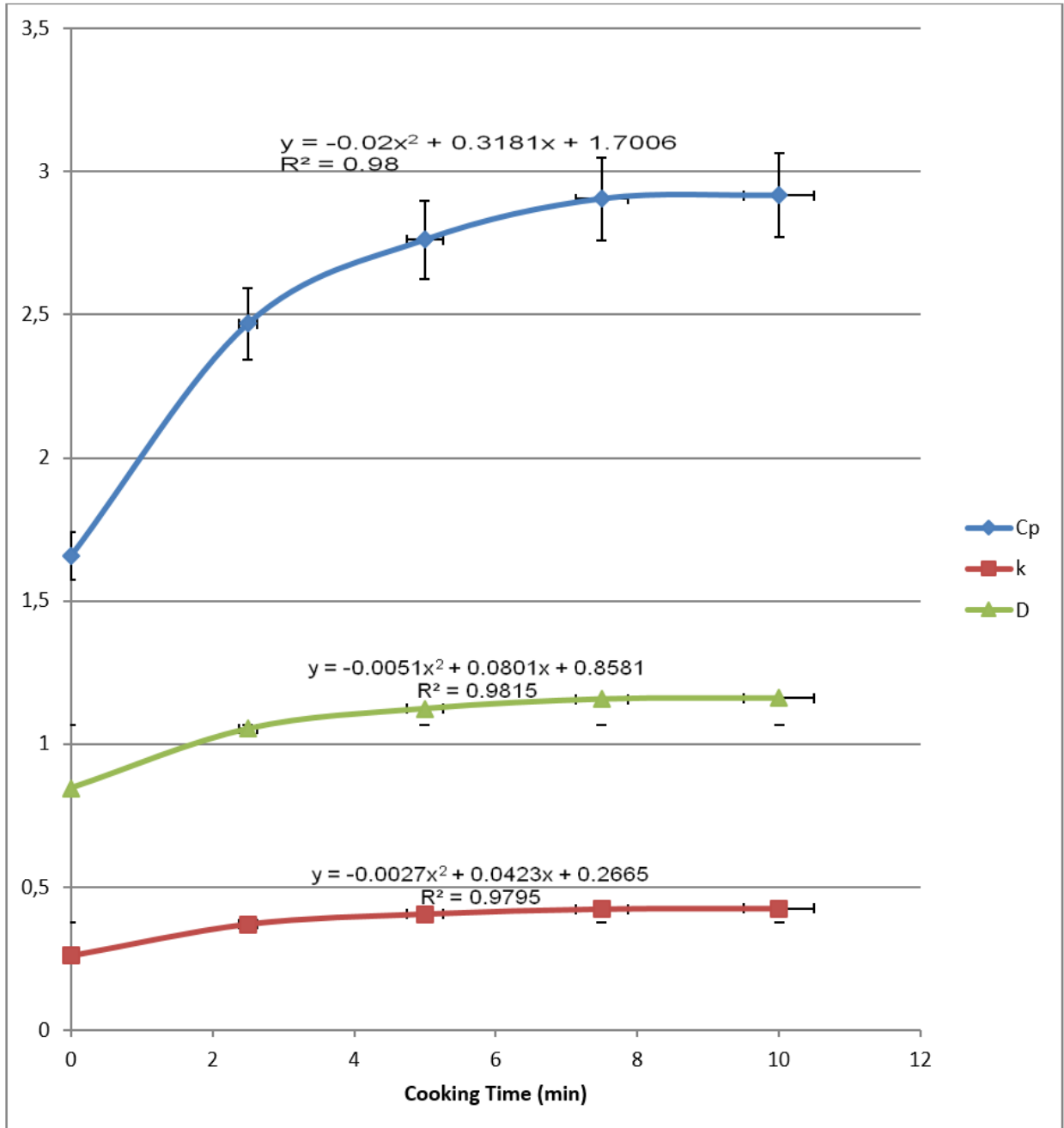

Figure 4: Effect of Cooking Time on the Thermal Properties of Brown Acha Seeds. $\mathrm{Cp}=$ Specific Heat Capacity, $\mathrm{kJkg}^{-1} \mathrm{~K}^{-1}, \mathrm{~K}=$ Thermal Conductivity, $\mathrm{Wm}^{-1} \mathrm{~K}^{-1}, \mathrm{D}=$ Thermal Diffusivity, $\mathrm{ms}^{-2} \cdot 10^{-7}$ 


\section{Conclusions}

All the physical properties measured showed some deviations from the average values which is typical of agricultural biomaterials. Cooking duration influenced the chemical and thermal properties of acha seeds. Effects of cooking time on the thermal properties of acha seeds were polynomial, thus an optimum cooking duration is required. The relationships between the moisture uptake of acha seeds during cooking and the thermal properties were linear. The model linear and polynomial equations established in this study had good fits. Cooking for 7.5 minutes was appropriate using the moisture uptakes as well as the thermal properties as criteria. Further cooking above 10 minutes might affect the chemical and thermal properties drastically. However, the generated data will be useful for selection of heat transfer medium and processing conditions.

\section{References}

Akinoso, R. \& Raji, A. O. (2011). Physical properties of fruit, nut and kernel of oil palm. International Agrophysics, 25(1), 85-88.

Akinoso, R. \& El-alawa, N. E. (2013). Some engineering and chemical properties of cooked locust bean seed (Parkia biglobosa). West Indian Journal of Engineering, 35(2), 51-57. Retrieved from http:// search.ebscohost.com/login $\cdot$ aspx? direct = true \& AuthType $=\mathrm{ip}$, uid \& db=a9h\&AN $=$ $112135810 \&$ site $=$ eds - live \& scope $=$ site \& authtype $=$ ip, cookie, uid

Akubugwo, I. E., Obasi, N. A., Chinyere, G. C., \& Ugbogu, A. E. (2007). Nutritional and chemical value of Amaranthus hybridus 1. leaves from afikpo, nigeria. African Journal of Biotechnology, 6(24), 2833-2839.

Altuntas, E. \& Yildiz, M. (2007). Effect of moisture content on some physical and mechanical properties of faba bean (vicia faba l.) grains. Journal of Food Engineering, 78(1), 174-183.

Andrejko, D., Rydzak, L., Slaska-Grzywna, B., Gozdziewska, M., \& Kobus, Z. (2008). Influence of preliminary thermal processing applying infra-red radiation on pea seeds cooking process. International Agrophysics, 22(1), 17-20.

AOAC. (2005). International, Association of Official Analytical Chemists. Official Methods of Analysis of the Association of Official Analytical Chemistry. Washington: AOAC. Retrieved from https://www.aoac.org

Aviara, N. A., Haque, M. A., \& Ogunjimi, L. A. O. (2008). Thermal properties of guna seed. International Agrophysics, 22(4), 291-297.

Baiyeri, K. P., Aba, S. C., Otitoju, G. T., \& Mbah, O. B. (2011). The effects of ripening and cooking method on mineral and proximate composition of plantain (Musa sp $A A B$ cv. 'agbagba') fruit pulp. African Journal of Biotechnology, 10(36), 6979 6984.

Bamgboye, A. I. \& Adejumo, O. I. (2010). Thermal properties of roselle seeds. International Agrophysics, 24(1), 85-87.

Barbosa-Canovas, G. V., Juliano, P., \& Peleg, M. (2006). Food engineering. encyclopaedia of life support systems (EOLSS). In G. V. Barbosa-Canovas (Ed.), (Chap. Engineering properties of foods, Vol. 1, pp. 3969). Oxford: EOLSS Publishers. Retrieved from http : / / www . eolss . net / ebooklib / ebookcontents/e5-10-themecontents.pdf

Chemperek, P. \& Rydzak, L. (2006). Vacuum wetting of soybean seeds and maize grains at different temperature and time conditions. Teka Kom. Energ. Roln, 24-31. Retrieved from http://www.pan-ol.lublin.pl/ wydawnictwa/TMot6a/Chemperek.pdf

Choi, Y. \& Okos, M. R. (1986). Food engineering and process applications. In M. L. Maguer \& P. Jelen (Eds.), (Chap. Effects of temperature and composition on the therma properties of foods, Vol. 1, pp. 93-101). London: Elsevier.

Chukwu, O., Sunmonu, M. O., \& Ismaila, I. (2011). Effects of cooking on the nutritional composition of wheat (@Triticum spp). International Journal of Academic Research, 3, 1113-1117. Retrieved from http : / / www . unilorin . edu . ng / index . php / faculty - of - engineering - technology / 3612 - sunmonu - musliu - olushola - agric biosystem-engineering- 1 
Cruz, J. F. (2004). Fonio: a small grain with potential. Low External Input and Sustainable Agriculture (LEISA). 20(16-17). Retrieved from http://edepot.wur.nl/90002

Davies, R. M. \& Zibokere, D. S. (2011). Effect of moisture content on some physical and mechanical properties of three varieties of cowpea (vigna unguiculata (l) walp). Agricultural engineering International: CIGR Journal, 13(1), Manuscript No. 1700.

Fellows, P. (2000). Food processing technology principles and practice. Woodhead Publishing Ltd., Cambridge, UK.

Fliedel, G., Ouattara, M., Grabulos, J., Drame, D., \& Cruz, J.-F. (2004). Effet du blanchiment mécanique sur la qualité technologique, culinaire et nutritionnelle du fonio, céréale d'afrique de l'ouest. Voies alimentaires d'amélioration des situations nutritionnelles en Afrique de l'Ouest: Le rôle des technologues alimentaires et des nutritionnistes: actes du 2e Atelier international, Ouagadougou, 23-28. Retrieved from http://agritrop.cirad.fr/526638/

Ishida, H., Suzuno, H., Sugiyama, N., Innami, S., Tadokoro, T., \& Maekawa, A. (2000). Nutritive evaluation on chemical components of leaves, stalks and stems of sweet potatoes (Ipomoea batatas poir). Food Chemistry, 68(3), 359-367. doi:10.1016/S03088146(99)00206-X

Jideani, A. I. \& Akingbala, J. O. (1993). Some physicochemical properties of acha (digitaria exilis stapf) and iburu (Digitaria iburua stapf) grains. Journal of the Science of Food and Agriculture, 63(3), 369-374. doi:10.1002/jsfa.2740630317

Kibar, H. \& Ozturk, T. (2008). Physical and mechanical properties of soybean. International Agrophysics, 22(3), 239-244.

Lasekan, D. O. (1994). Chemical composition of acha (Digitaria exilis) flour. Journal of Food Science and Agriculture, 14, 177-179.

Lewicki, P. P. (2004). Water as the determinant of food engineering properties. a review. Journal of Food Engineering, 61(4), 483495. 15th International Congress of Chemical Process Engineering (CHISA 2002), PRAGUE, CZECH REPUBLIC, AUG 25-
29, 2002. doi:10 . 1016 / S0260 - 8774(03 ) 00219-X

Mohsenin, N. (1986). Physical properties of plants and animal materials: structure, physical characteristics and mechanical properties. (pp. 94-96). New York: Gordon and Breach. Science Publishers Inc.

NAS. (1996). National Academy Press. Lost Crops of Africa: Grains. Washington: NAS. Retrieved from https:// www. nap.edu / $\mathrm{read} / 2305 /$ chapter $/ 1 \#$ iii

Obizoba, I. C. \& Anyika, J. U. (1994). Nutritive value of baobab milk (gubdi) and mixtures of baobab (Adansonia digitata 1 .) and hungry rice, acha (Digitaria exilis) flours. Plant Foods for Human Nutrition, 46(2), 157-165. doi:10.1007/BF01088768

Ogunsina, B. S. \& Koya, O. A. (2008). Deformation and fracture of dika nut (Irvingia gabonensis) under uni-axial compressive loading. International Agrophysics, 22, 249-253.

Olusanya, J. O. (2008). Essential of food and nutrition. In Apex Book Limited, Lagos, Nigeria (Ed.), (1st, pp. 36-76).

Seena, S., Sridhar, K. R., Arun, A. B., \& Young, C. C. (2006). Effect of roasting and pressure-cooking on nutritional and protein quality of seeds of mangrove legume Canavalia cathartica from southwest coast of india. Journal of Food Composition and Analysis, 19(4), 284-293. doi:10.1016/j . jfca.2005.05.004

Serna, S. (2003). Encyclopedia of food sciences and nutrition. In T. L. Caballero B \& Finglas (Eds.), (Chap. Cereals/Dietary Importance, pp. 1027-1033). London: Academic Press.

Singh, R. P. \& Heldman, D. R. (2001). Introduction to food engineering (3rd ed.). London: Academic Press.

Stroshine, R. \& Hamann, D. (1994). Physical properties of agricultural materials and food products: course manual. Purdue University Press, West Lafayette Indiana.

Tavakoli, H., Mohtasebi, S. S., \& Jafari, A. (2009). Physical and mechanical properties of wheat straw as influenced by moisture content. International Agrophysics, 23(2), $175-181$. 
Effect of Cooking Time on Properties of Acha Seeds |191

Tunde-Akintunde, T. Y. \& Akintunde, B. O. (2007). Effect of moisture content and variety on selected physical properties of beniseed. Agricultural Engineering International: CIGR Journal. Retrieved from http://hdl.handle.net/1813/10658 